\title{
Letter to the Editor regarding "The relationship between serum vitamin $D$ and fracture risk in the elderly: a meta-analysis"
}

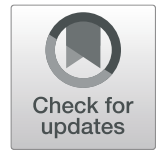

\author{
Li Qiujiang ${ }^{1,2+}$, Xingxia Long ${ }^{3+}$ and Lijun Cai ${ }^{1,2^{*}}$
}

\section{Dear Editor:}

We read with great interest the meta-analysis by Wang et al [1]. entitled "The relationship between serum vitamin D and fracture risk in the elderly: a meta-analysis." We congratulate the authors for publishing their study in this journal. Yet upon the review of this article, there are serious issues that nullify the conclusions. We seek certain clarifications from the authors.

First, the authors extensively searched the published literature through electronic databases (PubMed and Embase) and manually retrieved the references of the included studies, but these databases seemed to be not enough to retrieve all the eligible studies. Alternatively, other databases do exist, such as Cochrane Library, NLM Gateway, and BIOSIS previews as well as unpublished data like grey literature, which may contribute to get a more comprehensive collection of eligible studies.

Secondly, about the adaptation of systematic review guidelines and registrations, there have been systematic review and meta-analysis protocol registration established that help to maintain a level of homogeneity and quality across all meta-analyses and systematic reviews being conducted. The meta-analysis was performed following the guideline of PRISMA, but the pre-defined protocol was not registered in any platform, such as the Cochrane Library and PROSPERO $[2,3]$. Not only do the registration provides transparency in the review, but

\footnotetext{
* Correspondence: cqsgklqj@163.com

${ }^{\dagger}$ Qiujiang li and Xingxia long contributed equally to this manuscript ${ }^{1}$ Graduate School of Ningxia Medical University, Yinchuan, Ningxia Hui Autonomous Region, China

2Department of Spine Surgery, People's Hospital of Ningxia Hui Autonomous Region, No. 56, Zhengyuan Street, Yinchuan 750000, Ningxia Hui Autonomous Region, China

Full list of author information is available at the end of the article
}

also improves the quality of conduct of the review and its subsequent reporting.

Thirdly, In total, 20 studies met inclusion criteria and were included in the meta-analysis. Given the characteristics of the study of Swanon et al. [4] in Table 1, such as the study type, number of total fractures, number of hip fractures, country and period, were similar to the study of Cauley et al. [5], we doubt this is the case. Upon close examination, a main reason we found was both of the two studies were case-cohort within the Osteoporotic Fractures in Men Study (MrOS), which recruited 5994 community-dwelling men at six clinical centers in the USA (Birmingham, Alabama, Minneapolis, Minnesota, Palo Alto, California, Monongahela Valley near Pittsburgh, Pennsylvania, Portland, Oregon, and San Diego, California) between March 2000 and April 2002 for a study on musculoskeletal aging. If extracting duplicate data for the sample, it would be likely to lead to an incorrect conclusion, misleading clinical practice. Therefore, in case that several articles from the same trial were published, the study that had the most relevant information or the longest follow-up period might be most appropriate.

Fourthly, Wang et al. [1] revealed that BMI (body mass index) may be a key risk factor to cause osteoporosis and osteoporotic fractures in patients (patients aged 65 and above). Therefore, it is better to perform a subgroup analysis of the low and normal and high BMI in the current study to clear the effect of BMI. Finally, we hope that the authors address the points presented and that the overall discussion of the presented points will only serve to benefit the research community at large. 


\section{Acknowledgements}

None.

\section{Authors' contributions}

QL wrote this manuscript. XL and $L C$ reviewed the selected studies in Wang et al.'s review. All authors read and approved the final manuscript.

\section{Funding}

None.

\section{Availability of data and materials}

Not applicable.

\section{Ethics approval and consent to participate}

Not applicable.

\section{Consent for publication}

Not applicable.

\section{Competing interests}

The authors declare that they have no competing interests

\section{Author details}

${ }^{1}$ Graduate School of Ningxia Medical University, Yinchuan, Ningxia Hui Autonomous Region, China. ${ }^{2}$ Department of Spine Surgery, People's Hospital of Ningxia Hui Autonomous Region, No. 56, Zhengyuan Street, Yinchuan 750000, Ningxia Hui Autonomous Region, China. ${ }^{3}$ Graduate School of Huzhou University, Huzhou, Zhejiang Province, China.

Received: 16 April 2020 Accepted: 22 July 2020

Published online: 07 August 2020

\section{References}

1. Wang N, Chen Y, Ji J, et al. The relationship between serum vitamin D and fracture risk in the elderly: a meta-analysis. J Orthop Surg Res. 2020;15(1):81.

2. David $M$, Alessandro $L$, Jennifer $T$, et al. Preferred reporting items for systematic reviews and meta-analyses: the PRISMA statement. Ann Intern Med. 2009;151:264-9 W64.

3. Stroup Donna F, Berlin Jesse A, Morto Sally C, et al. Meta-analysis of observational studies in epidemiology: a proposal for reporting. Metaanalysis of observational studies in epidemiology (MOOSE) group. JAMA. 2000;283:2008-12.

4. Swanson CM, Srikanth $P$, Lee CG, et al. Associations of 25-hydroxyvitamin D and 1,25-dihydroxyvitamin $\mathrm{D}$ with bone mineral density, bone mineral density change, and incident nonvertebral fracture. J Bone Miner Res. 2015; 30(8):1403-13.

5. Cauley JA, Parimi N, Ensrud KE, et al. Serum 25-hydroxyvitamin D and the risk of hip and nonspine fractures in older men. J Bone Miner Res. 2010; 25(3):545-53.

\section{Publisher's Note}

Springer Nature remains neutral with regard to jurisdictional claims in published maps and institutional affiliations.

Ready to submit your research? Choose BMC and benefit from:
- fast, convenient online submission
- thorough peer review by experienced researchers in your field
- rapid publication on acceptance
- support for research data, including large and complex data types
- gold Open Access which fosters wider collaboration and increased citations
- maximum visibility for your research: over 100M website views per year
At BMC, research is always in progress.
Learn more biomedcentral.com/submissions

